Indexed by

\title{
ANALYSIS OF TENSILE STRENGTH,
Scopus
CRYSTALLINITY, CRYSTALLITE SIZE, AND THERMAL STABILITY OFPOLYPROPYLENE JOINED BY FRICTION STIR WELDING
}

Crossref

KORSON

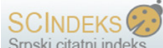

엠oogle

\author{
Bambang Kusharjanta \\ Universitas Sebelas \\ Maret Surakarta, Mechanical \\ Enginering, Surakarta, \\ Indonesia \\ Universitas Brawijaya, \\ Mechanical Engineering, \\ Brawijaya, \\ Indonesia

\section{Yudy Surya Irawan} \\ Universitas Brawijaya, \\ Mechanical Engineering, \\ Brawijaya, \\ Indonesia
}

\author{
Anindito Purnowidodo \\ Universitas Brawijaya, \\ Mechanical Engineering, \\ Brawijaya, \\ Indonesia
}

Key words: friction stir welding, crystallinity, tensile strength, polypropylene doi:10.5937/jaes0-30899

Cite article:

Kusharjanta B., Soenoko R., Purnowidodo A., Surya Irawan Y.

(2022) ANALYSIS OF TENSILE STRENGTH, CRYSTALLINITY, CRYSTALLITE SIZE, AND THERMAL STABILITY OF POLYPROPYLENE JOINED BY FRICTION STIR WELDING, Journal of Applied Engineering Science, 20(1), 85 - 90, DOI:10.5937/ jaes0-30899

Online aceess of full paper is available at: www.engineeringscience.rs/browse-issues 


\title{
ANALYSIS OF TENSILE STRENGTH, CRYSTALLINITY, CRYSTALLITE SIZE, AND THERMAL STABILITY OF POLYPROPYLENE JOINED BY FRICTION STIR WELDING
}

\author{
Bambang Kusharjanta1,2*, Rudy Soenoko², Anindito Purnowidodo², Yudy Surya Irawan² \\ ${ }^{1}$ Universitas Sebelas Maret Surakarta, Mechanical Enginering, Surakarta, Indonesia \\ Universitas Brawijaya, Mechanical Engineering, Brawijaya, Indonesia
}

This paper aims to investigate the joining of polypropylene using friction stir welding (FSW). FSW parameters were the rotation speed of $620 \mathrm{rpm}$, the travel speed of $7.3 \mathrm{~mm} / \mathrm{min}$, and $13 \mathrm{~mm} / \mathrm{min}$. The tensile test was using a universal testing machine, and the results of the tensile test were related to the degree of crystallinity. X-ray diffraction (XRD) examined the crystallite size and degree of crystallinity. The thermal analysis was using thermogravimetry analysis/ differential scanning calorimetry (TGA/DSC). This paper explained the degree of crystallinity effects on the thermal stability at the weld nugget area due to travel speed. The findings showed FSW with a travel speed of $7.3 \mathrm{~mm} / \mathrm{min}$ had a bigger crystallite size and degree of crystallinity than that with a travel speed of $13 \mathrm{~mm} / \mathrm{min}$. There was a fusion of crystals also recrystallization occurred. It was an effect of the difference in the length of time exposed to heat during the FSW process. A travel speed of $7.3 \mathrm{~mm} / \mathrm{min}$ sample had high tensile strength because it obtained sufficient heat for an extra complete joint. In terms of thermal stability, the specimen with a lower travel speed showed a higher stability level than the specimen with a higher travel speed in the higher degree of crystallinity.

Key words: friction stir welding, crystallinity, tensile strength, polypropylene

\section{INTRODUCTION}

The use of polymers would be more feasible if the joining can be done. Recently, the investigation of several popular joining methods occurred, some of which were mechanical fastening and adhesive bonding [1]. Moreover, welding of the polymer could be one of the potential methods to join polymer materials that polymer welding dividing into three categories depending on the source of heating: heat conduction, heat radiation, and mechanical friction. The latter then classified into two types: friction welding (FW) and friction stir welding (FSW) [2].

The Welding Institute in the 1990s firstly developed FSW. This technique was initially to join metals yet developed to polymers, especially thermoplastics [3]. The process of FSW was a method centrally using a rotating tool. This tool has a shoulder that rotates on the surface of the materials and a pin immersed at the joining line of two adjoining workpieces. The adjoining workpieces could be successful due to the heat resulted from friction between the shoulder and surface of workpieces and the effect of pin stirring [4].

The investigation on the tensile strength of acrylonitrile butadiene styrene (ABS) joined through the FSW method showed that the strength was lower than the tensile strength of base materials. The rotating tool generated heat which induced the plasticizing polymer process and forced the mixture of materials. The morphology of the welding was caused by the difference in the rotation and transverse speed. This experiment used a rotational speed of 1000 and $1500 \mathrm{rpm}$, the transverse pace of 50 and 200 $\mathrm{mm} / \mathrm{min}$, and an axial force of from $0.75 \mathrm{kN}$ to $4 \mathrm{kN}$ [5].
Another study used Nylon-6 to understand the effect of the rotational pin on the mechanical properties, crystal growth, and fracture analysis [6]. The study showed that nylon- 6 joined using FSW at the low speed produces a better quality of joint than that at a higher velocity.

FSW method for polyethylene sheets performed underwater produces a maximum tensile strength of 12.3 MPa, higher than the original condition. Besides, the crystallinity of the base material, heat a zone affected (HAZ), thermo-mechanical affected zone (TMAZ), and weld nugget constituted $54.4 \%, 54.0 \%, 51.1 \%$ dan $48.2 \%$ sequentially observed using Small Angle X-Ray Scattering (SAXS) [7]. It also studied the relation between the degree of crystallinity and tensile strength. The findings of this study showed that the increase in crystallinity improves the joining [7].

Some papers about FSW focus on the degradation of materials caused by heat derived from tool pin friction and workpieces. The higher heating temperature caused the degradation of high-density polyethylene (HDPE) polymeric chains in the stir zone area [8]. Degradation occured due to the low transverse speed of FSW made the materials exposed to heating for a longer time. This degradation of materials reduced the tensile strength of the joining. The material in this experiment is polyethylene (PE) and polypropylene (PP) [9].

Furthermore, another study (Bertin et al. 2010) revealed that the polypropylene material degrades when it experiences high temperatures, more than $200^{\circ} \mathrm{C}$. Degradation of the polypropylene processed by multiple ex- 
truders also occurs. Properties that were affected were yield stress, modulus, and impact strength. Meanwhile, polymathic-methacrylate and polystyrene polymers that undergone processing in the screw extruder will experience degradation due to high temperatures. Mechanical stress at high temperatures accelerated the degradation leading to a decrease in molecular weight [10].

In some of the articles mentioned above, there were reports about the various mechanical properties of the FSW process. Besides, polypropylene had also been proclaimed to be degraded due to automated processes with the extruder. This process involved high temperature and processes. It was similar to the FSW process as a high temperature due to friction between the shoulder-pin tool and workpieces and mechanical processes in compressive forces and frictional forces due to tool rotation [11].

This paper discussed the tensile strength of polypropylene friction stir welded at the tool rotation speed of 620 $\mathrm{rpm}$ and travel speed of $7.3 \mathrm{~mm} / \mathrm{min}$ and $13 \mathrm{~mm} / \mathrm{min}$. Conjecturing its relation to material degradation, crystallinity, and crystallite size due to high-temperature exposure. The FSW of polypropylene was still rarely done in the referenced paper. Therefore, the exploration of the character of the polypropylene FSW became an interesting object in the research.

\section{MATERIALS AND METHODS}

The material used in this experiment was polypropylene with a thickness of $6 \mathrm{~mm}$ (Rochling, obtained from Sumber Jaya Engineering Plastics, Indonesia). Table 1 and Table 2 sequentially showed the mechanical and thermal properties of polypropylene cut into a rectangle with a size of $250 \times 150 \mathrm{~mm}$. These dimensions were for clamping installation on the bench.

FSW was performed with an FSW tool shown in Figure 1. The shoulder used was flat. The pins ended on the left and right side; a cut was at an angle of 450 against the FSW tool axis. The FSW operated using a conventional milling machine and carried out with a tilt angle of 00 and plunge depth of $0.02 \mathrm{~mm}$. The $12 \mathrm{~mm}$ thick steel plate on the milling machine bench was a basis for workpieces shown in Figure 2. FSW welding parameters were rotational speed of $620 \mathrm{rpm}$ and travel speed of $7.3 \mathrm{~mm} /$ $\mathrm{min}$ and $13 \mathrm{~mm} / \mathrm{min}$. Meanwhile, the tool pin used was made of AISI 4140 steel with a shoulder diameter of 18 $\mathrm{mm}$ and a shoulder length of $90 \mathrm{~mm}$. The tool pin used for the FSW process was the diameter of $4.5 \mathrm{~mm}$ and the tool pin length of $5.7 \mathrm{~mm}$.

After the FSW welding process was complete, the workpiece was then cut to make a tensile test sample and adapted ASTM D638, XRD test sample, and DSC/TGA test. The tensile test sample measuring $12 \mathrm{~mm}$ wide was cut perpendicular to the weld line shown in Figure 3. The number of tensile test samples was five samples for each FSW welding parameter. A tensile test was using the Universal Testing Machine with a displacement rate of $10 \mathrm{~mm} / \mathrm{min}$. The XRD samples were from the base material and the welding section, in the form of flakes about $3 \mathrm{~mm}$ in size, and the TGA/DSC samples in the form of powder were also taken from the welding section.

Table 1: Mechanical Properties of Polypropylene [12]

\begin{tabular}{|c|c|c|}
\hline Properties & Number & Unit \\
\hline Tensile strength & 33 & $\mathrm{MPa}$ \\
\hline Elongation at break & 148 & $\%$ \\
\hline Ball indentation hardness & 75 & $\mathrm{~N} / \mathrm{mm}^{2}$ \\
\hline Notched Impact Charpy Strength & 1.26 & $\mathrm{~J} / \mathrm{cm}^{2}$ \\
\hline Modulus of elasticity & 1450 & $\mathrm{~N} / \mathrm{mm}^{2}$ \\
\hline Density & 1 & $\mathrm{gr} / \mathrm{cm}^{3}$ \\
\hline Coefficient of friction & 0.25 & - \\
\hline
\end{tabular}

Table 2: Thermal properties of Polypropylene [12]

\begin{tabular}{|c|c|c|}
\hline Maximum Cont. Operating Temp. & Units & Values \\
\hline Linier Expansion Factor @ $23^{\circ} \mathrm{C}$ & $\mathrm{K}-1$ & $1.5 \times 10^{-4}$ \\
\hline Thermal Conductivity @ $23^{\circ} \mathrm{C}$ & $\mathrm{W} /\left(\mathrm{m}^{*} \mathrm{~K}\right)$ & 0.22 \\
\hline
\end{tabular}
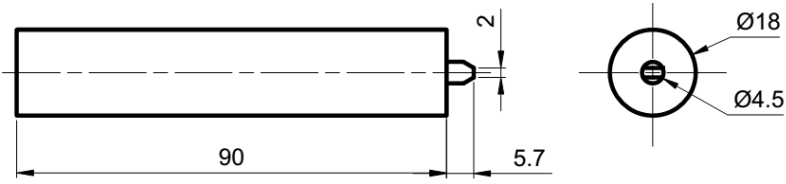

Figure 1: Tool for FSW Polypropylene

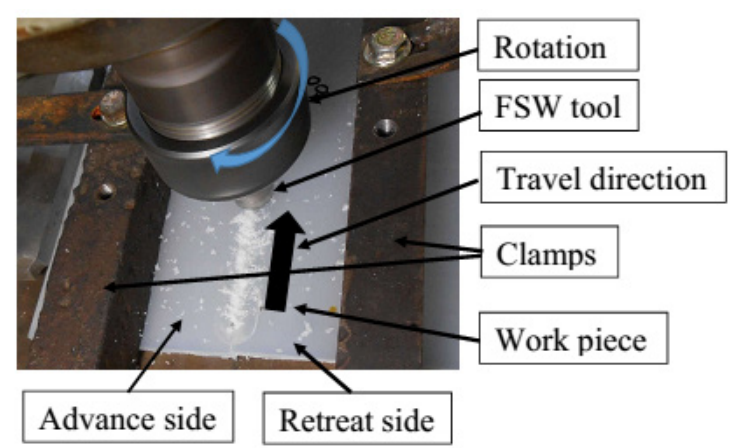

Figure 2: Friction Stir Welding of Polypropylene

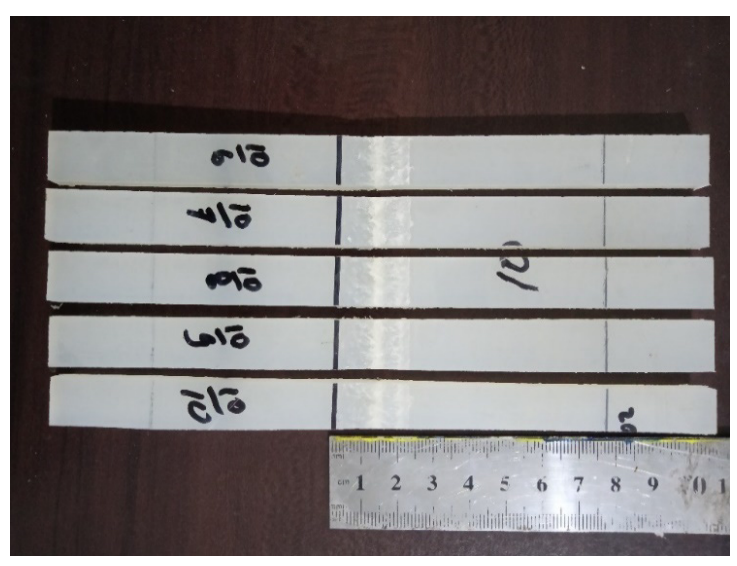

Figure 3: Tensile test specimens of FSW polypropylene

All samples in this experiment coded as shown in table 3. 
Table 3: Polypropylene Friction Stir Welded samples code

\begin{tabular}{|c|c|c|}
\hline \multicolumn{2}{|c|}{ Welding Parameters } & Code \\
\hline Rotation (rpm) & $\begin{array}{c}\text { Travel Speed } \\
\text { (mm/min) }\end{array}$ & \\
\hline na & na & BM \\
\hline 620 & 7.3 & $620-7.3$ \\
\hline 620 & 13 & $620-13$ \\
\hline
\end{tabular}

\section{RESULTS AND DISCUSSION}

\section{Tensile strength}

The results of the tensile test on the sample shown in Figure 4. Specimen $620-7.3$ had a tensile strength of $22.41 \mathrm{~N} / \mathrm{mm}^{2}$. The $620-7.3$ unit was higher than the FSW sample 620-13. This condition was to occur because the sample 620-7.3 got sufficient heating which would cause the flow of soft material to produce a perfect joint. It also happened in an experiment conducted by Sahu et al. 2018, [13]. Afterward, the different tensile strength was also by the degree of crystallinity calculated by [14]

$X_{c}=\frac{A_{c}}{A_{c}+A_{a}}$

whereas $X_{c}, A_{a}$, and $A_{c}$, were the degree of crystallinity, amorphous area, and crystalline area. The samples from the FSW process shown tensile strength correlated with crystallinity shown in Figure 4 and Figure 8 . This fact had also been found in the FSW polyamide- 66 process by the previous researcher [15].

Apart from the influence of the degree of crystallinity, the weld joint quality determined tensile strength. Joints that had a considerably feeble weld zone and porous (indicated by a few arrows), in Figure 5 and Figure 6, had poor tensile strength. The tensile strength was different from the base material with a higher tensile strength because it as not porous. This zone occured presumably due to insufficient heat as the pin tool left the workpiece faster. It caused the workpiece to cool quicker, so if the high travel speed would reduce the heat compared to the FSW process with a low travel speed and caused a defective weld zone as shown in figure $4 \mathrm{~b}$. There was no enough material consolidation to form a perfect joint which led to low tensile strength. Excessive travel speed also caused discontinuation of the weld zone and reduced tensile strength. Welding efficiencies for samples $620-7.3$ and $620-13$ were $67.9 \%$ and $35.4 \%$. The statement was under the results obtained by previous researchers [16] [17].

\section{Crystallite size and degree of crystallinity}

The XRD pattern of FSW polypropylene and base material (BM) was in Figure 7. Crystallite size and degree of crystallinity were in Figure 8 . The degree of crystallinity changes occurred because the heating and cooling

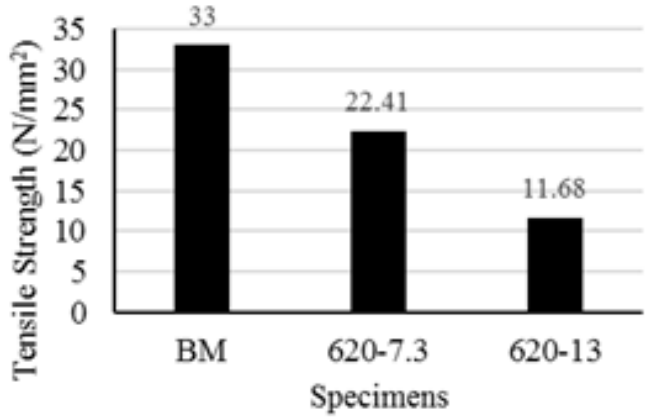

Figure 4: Tensile Strength of Friction Stir Welding of Polypropylene and base material

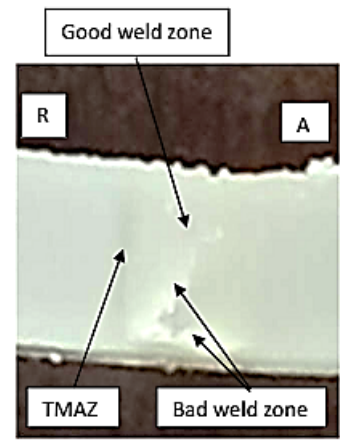

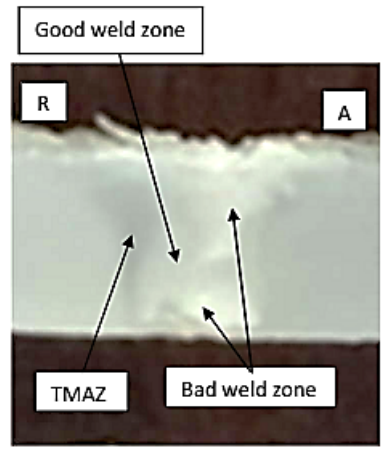

b.
Figure 5: Cross sectional area of FSW polypropylene a) $620 \mathrm{rpm}$ rotation- $7.3 \mathrm{~mm} / \mathrm{min}$ travel speed, b) $620 \mathrm{rpm}$ rotation- $13 \mathrm{~mm} / \mathrm{min}$ travel

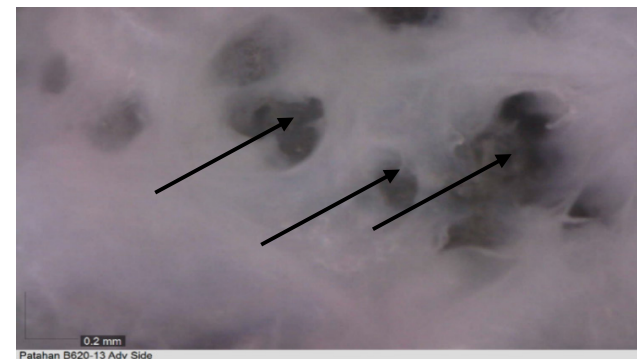

Figure 6: The fracture surface of the tensile specimen of FSW polypropylene

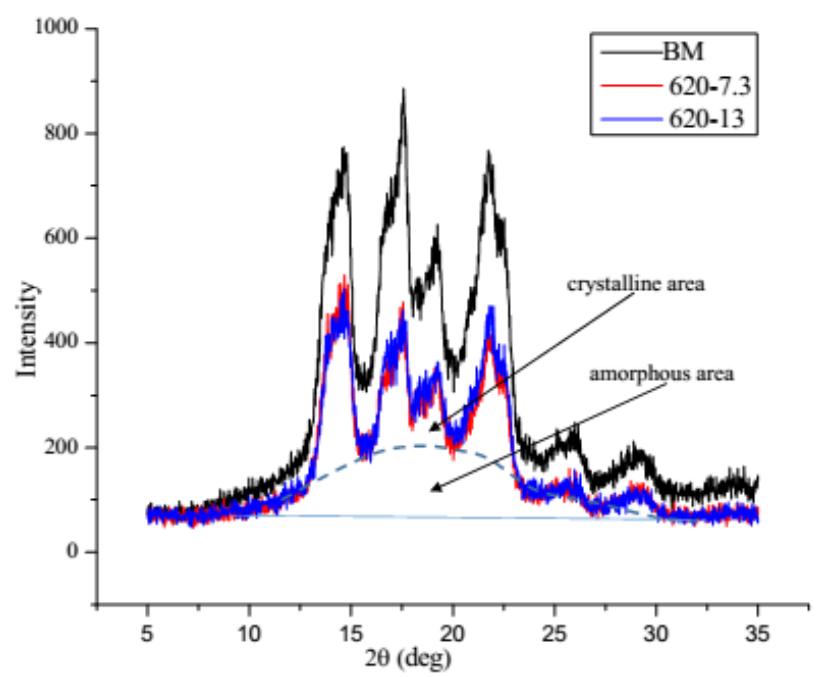

Figure 7: XRD pattern of FSW polypropylene and base material (BM) 


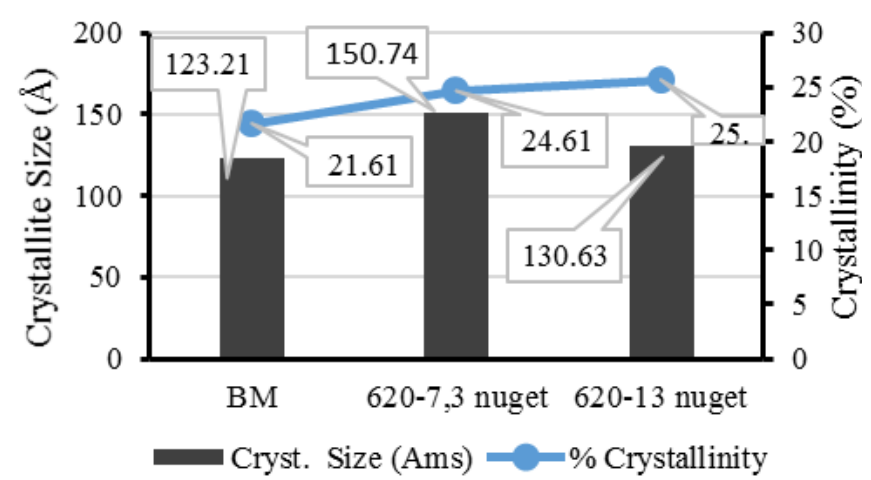

Figure 8: Crystal size-Crystallinity of friction stir welding of polypropylene and base material

accompanied the pressure in the FSW process. Aghajani et al [18] investigated this fact as well. At sample 620-13, there was a faster cooling than sample 620-7.3. The higher travel speed caused the tool pin to leave the welding zone faster than at low travel speed, so the workpiece cooled quicker, estimated in not much recrystallization of the material. As a result, more amorphous structures formed so that there would be a decrease in the degree of crystallinity. It differed from sample 6207.3 in that it was proceeding with a slow cooling rate that occurred so that more crystalline structures were formed and produced a higher degree of crystallinity, as shown in figure 8. This fact follows the research conducted by S. Saeedy and M. K. Besharati (2011) [17].

Further fact, there is a crystallite size difference between the base material (BM) sample 620-7.3 and sample 62013. The values were $123.21 \AA, 150.74 \AA$, and $130.63 \AA$, as shown in figure 8 . It was due to the longer heating time occurring at samples 620-7.3. This statement was following the finding of S. Saeedy and M. Beshariti [17]. The length of time of exposing the material to heat affected the crystallite size of the specimens. Crystallite size correlated with the temperature. The increase in crystallite size due to the influence of the fusion of adjacent crystals. As an influence of this combination, the crystallite size was larger than the material unexposed to the heat as it followed the research conducted by P. Gu et al. (2019) [19].

\section{TGA/DSC Analysis of polypropylene}

Figure 9 showed the thermogravimetric analysis (TGA) curve. The differential scanning calorimetry (DSC) curve as in Figure 10. Both curves showed the results for base material sample (BM) and joint sample 620-7.3 and sample $620-13$. Table 3 was recording data from these two curves. The base material and FSW sample only shown one degradation stage, as shown in Figure 9. This fact shown that all the specimens consisted only of polypropylene and did not contain any other components. The TGA curves appeared to be overlapping, which indicated that there was no significant difference in the degradation temperature of all samples [20].

The initial temperature of degradation was at tempera- tures from around $208.580 \mathrm{C}$ for $\mathrm{BM}$ to $219.27^{\circ} \mathrm{C}$ in sample 620-7.3, while sample 620-13 FSW had an initial temperature of degradation $212.63^{\circ} \mathrm{C}$. This difference was related to the degree of crystallinity of each specimen. The higher the crystallinity, the higher the initial temperature of degradation, which would increase the thermal stability [21].

In Figure 10, several points become sample characters. The first peak indicated the crystallization temperature (T-Cr) and as in table 4. The crystallization temperature for all FSW samples was around $130^{\circ} \mathrm{C}$. The FSW process did not involve material components so that the weld nugget FSW material remained like the base material. The temperature observed was also under the research conducted by previous researchers [22]. The second peak was the melting temperature, collected in table 4 . The melting heat did not have a significant value difference, which meant that the FSW process did not affect the melting temperature of polypropylene. The melting heat in this research was close to the value obtained by other researchers [20].

The third point is the initial degradation temperature (T-ID) of $208.58^{\circ} \mathrm{C}$ of $\mathrm{BM}, 219.27^{\circ} \mathrm{C}$ of $620-7.3$, and $212.63^{\circ} \mathrm{C}$ for $620-13$ samples.

Sample $620-7.3$ had the highest T-ID value of $219,27^{\circ} \mathrm{C}$. T-ID was a property that correlated with the degree of crystallinity which was also the highest among the samples. The degree of crystallinity and crystallite size was proportional to the T-ID shown in Figure 8 and Table 4. These facts were according to Poletto et al [24]. This T-ID value was also a parameter that indicated the character of thermal stability. If the T-ID value was higher, the material would begin to degrade at high temperatures or has high thermal stability [25].

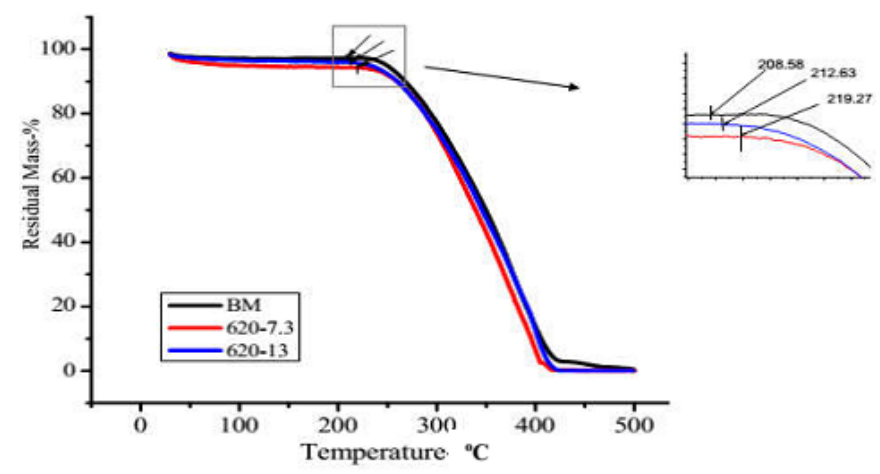

Figure 9: Thermography metric analysis (TGA) curve of base material and FSW polypropylene samples

The next peak, in Figure 10, was the burning temperature (TB) of $436.01^{\circ} \mathrm{C}, 423.52^{\circ} \mathrm{C}$, and $427.98^{\circ} \mathrm{C}$ and residual mass of $2.74 \%, 0.32 \%$, and $0.35 \%$, in table 4 , for BM samples, $620-7.3$ and $620-13$ respectively. The burning temperature values for these three samples were close. It was the temperature of all material degraded that left a residue in the form of ash [26]. 
Table 4: Temperatures of thermal properties FSW polypropylene and base material

\begin{tabular}{|c|c|c|c|c|c|c|}
\hline \multicolumn{2}{|c|}{ Welding Parameters } & \multirow[b]{2}{*}{ Code } & \multirow[b]{2}{*}{$\begin{array}{l}\mathrm{T}-\mathrm{Cr} \\
\left({ }^{\circ} \mathrm{C}\right)\end{array}$} & \multirow[b]{2}{*}{$\begin{array}{l}\text { T-m } \\
\left({ }^{\circ} \mathrm{C}\right)\end{array}$} & \multirow[b]{2}{*}{$\begin{array}{l}\text { T-ID } \\
\left({ }^{\circ} \mathrm{C}\right)\end{array}$} & \multirow[b]{2}{*}{$\begin{array}{l}\text { T-B } \\
\left({ }^{\circ} \mathrm{C}\right)\end{array}$} \\
\hline $\begin{array}{l}\text { Rotation } \\
\text { (rpm) }\end{array}$ & $\begin{array}{c}\text { Travel Speed } \\
\text { (mm/min) }\end{array}$ & & & & & \\
\hline na & na & BM & 133.84 & 155.77 & 208.58 & 436.01 \\
\hline 620 & 7.3 & $620-7.3$ & 127.08 & 154.97 & 219.27 & 423.52 \\
\hline 620 & 13 & $620-13$ & 135.08 & 156.17 & 212.63 & 427.98 \\
\hline
\end{tabular}

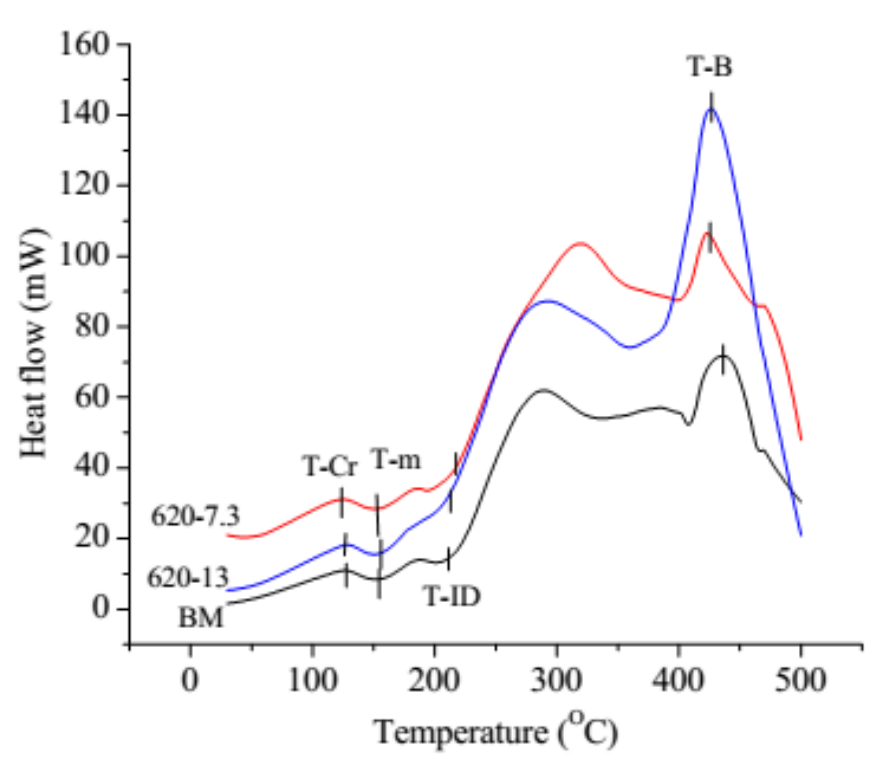

Figure 10: Differential scanning calorimetry (DSC) curve of base material and FSW polypropylene samples

\section{CONCLUSIONS}

This paper presented some results on thermoplastic FSW. FSW research was also on PP plates with a thickness of $6 \mathrm{~mm}$. Furthermore, the joining of polypropylene utilizing friction stir welding has been successfully carried out with the highest tensile strength of $22.41 \mathrm{MPa}$, lower than the tensile strength of the base material of 33 $\mathrm{MPa}$. The FSW process provided heat exposure to the material. It increased the crystallinity degree and crystallite size in the weld zone of polypropylene materials. Also, there was an increase in thermal stability in the weld zone compared to the base material of polypropylene. Future work proposed was an attempt to increase the strength of the polypropylene FSW joint with a variety of parameters not yet investigated.

\section{ACKNOWLEDGMENTS}

The author appreciations the Ministry of Education and Culture of the Republic of Indonesia, for supporting this research in the doctoral program at Universitas Brawijaya, Malang, Indonesia.

\section{REFERENCES}

1. Huang, Y., Meng, X., Xie, Y., Wan, L., Lv, Z., Cao, J., and Feng, J. (2018). Friction stir welding/processing of polymers and polymer matrix composites. Compososites: Part A Applied Science and Manufacturing, vol. 105, pp. 235-257, DOI 10.1016/j.compositesa.2017.12.005.

2. Kiss, Z., and Czigány, T. (2007). Applicability of friction stir welding in polymeric materials. Perioda Polytechnica, vol. 51, no. 1, pp. 15-18, DOI 10.3311/ pp.me.2007-1.02.

3. Kiss, Z., and Czigány, T. (2012). Microscopic analysis of the morphology of seams in friction stir welded polypropylene. Express Polymer Letters, vol. 6, no. 1, pp. 54-62, DOI 10.3144/expresspolymlett.2012.6.

4. Ethiraj, N., Meikeerthy, S., and Sivabalan, T. (2020). Submerged friction stir welding: An overview of results of experiments and possible future works. Engineering and Applied Science Research, vol. 47, no. 1, pp. 111-116, DOI 10.14456/easr.2020.11.

5. Mendes, N., Loureiro, A., Martins, C., Neto, P., and Pires, J. N. (2014). Effect of friction stir welding parameters on morphology and strength of acrylonitrile butadiene styrene plate welds. Materials and Design, vol. 58, pp. 457-464, DOI 10.1016/j.matdes.2014.02.036.

6. Panneerselvam, K., and Lenin, K. (2014). Joining of Nylon 6 plate by friction stir welding process using threaded pin profile. Material and Design, vol. 53, pp. 302-307, DOI 10.1016/j.matdes.2013.07.017.

7. Gao, J., Shen, Y., Zhang, J., and Xu, H. (2014). Submerged Friction Stir Weld of Polyethylene Sheets. Journal of Applied Polymer Science, pp. 1-8, DOI 10.1002/app.41059

8. Mostafapour, A. and Azarsa, E. (2012). A study on the role of processing parameters in joining polyethylene sheets via heat-assisted friction stir welding : Investigating microstructure, tensile and flexural properties. International Journal of The Physical Sciences, vol. 7, no. 4, pp. 647-654, DOI 10.5897/ IJPS11.1653.

9. Eslami, S., Ramos, T., Tavares, P. J., and Moreira, P. M. G. P. (2015). Effect of Friction Stir Welding Parameters with Newly Developed Tool for Lap Joint of Dissimilar Polymers. Procedia Engineering, vol. 114, pp. 199-207, DOI 10.1016/j.proeng.2015.08.059. 
10. Capone, C., Landro, Di, L., Inzoli, F., Penco, M., Sartore, L., and Vinci, L. (2007). Thermal and Mechanical Degradation During Polymer Extrusion Processing. Polymer Engineering and Science, pp. 4-10, DOI 10.1002/pen.20882.

11. Kumar, R., Singh, R., Ahuja, I. P. S., Penna, R., and Feo, L. (2018). Weldability of thermoplastic materials for friction stir welding- A state of the art review and future applications. Composites Part B, vol. 137, no. October 2017, pp. 1-15, DOI 10.1016/j.compositesb.2017.10.039.

12. Jaya S. (2018). Product Catalogue. Sumber Jaya Stockist and Supplier, Jakarta, Indonesia.

13. Sahu S. K., Mishra, D., Mahto, R. P., Sharma, V. M., Pal, S. K., Pal, K., Banerjee, S., and Dash, P. (2018). Friction stir welding of polypropylene sheet, Engineering Science and Technology, an International Journal, vol. 21, no. 2, pp. 245-254, DOI 10.1016/j. jestch.2018.03.002

14. Lei, F., Yu, H., Yang, S., Sun, H., Li, J., Guo, S., Wu, H., Shen, J., Chen, R., and Xiong, Y. (2016). Analysis of crystalline structure and morphology of isotactic polypropylene under the coexistence of organic montmorillonite particles and shear flow, Polymer, vol. 82, pp. 274-284, DOI 10.1016/j.polymer.2015.11.053.

15. Nandhini, R., Kumar, R. D., Muthukumaran, S., and Kumaran, S. (2019). Analysis of Mechanical and Crystalline Characteristics of Polyamide 66 Joints Welded by a Novel Friction Stir Welding, Arabian Journal for Science and Engineering, DOI 10.1007/ s13369-019-03770-5

16. Simões, F., and Rodrigues, D. M. (2014). Material flow and thermo-mechanical conditions during Friction Stir Welding of polymers: Literature review, experimental results, and empirical analysis, Materials and Design, vol. 59, pp. 344-351, DOI 10.1016/j. matdes.2013.12.038.

17. Saeedy S., and Besharati, M. K. (2011). Investigation of the effects of critical process parameters of friction stir welding of polyethylene, Proceedings of the Institution of Mechanical Engineers, Part B: Journal of Engineering Manufacture, vol. 225, no. 8, pp. 1305-1310, DOI 10.1243/09544054JEM1989.

18. Aghajani, H., Simchi, A., and Lambiase, F. (2019). Friction stir welding of polycarbonate lap joints : Relationship between processing parameters and mechanical properties, Polymer Testing, vol. 79, DOI 10.1016/j.polymertesting.2019.105999.
19. Gu, P., Zhu, X., and Yang, D. (2019). Effect of annealing temperature on the performance of photoconductive ultraviolet detectors based on $\mathrm{ZnO}$ thin films, Applied Physics A: Materials Science and Processing, vol. 125, no. 50, pp. 1-8, DOl 10.1007/ s00339-018-2361-3.

20. Mofokeng, J. P., Luyt, A. S., Tábi, T., and Kovács, J. (2012). Comparison of injection-molded, natural fiber-reinforced composites with PP and PLA as matrices, Journal of Thermoplastic Composite Materials, vol. 25, no. 8, pp. 927-948, DOI 10.1177/0892705711423291.

21. Motlagh, N. K., Khonakdar, H. A., Jafari, S. h., Sarmad, M. P., Javadi, A., and Goodarzi, V., (2019). An experimental and theoretical mechanistic analysis of thermal degradation of polypropylene/polylactic acid/clay nanocomposites, Polymer Advanced Technologies, vol. 30, no. 11, pp. 2695-2706, DOI 10.1002/pat.4699.

22. Gradys, A., Sajkiewicz, P., Minakov, A. A., Adamovsky, S., Schick, C., Hashimoto, T., and Saijo, K. (2005). Crystallization of polypropylene at various cooling rates, Materials Science and Engineering $A$, vol. 413-414, pp. 442-446, DOI 10.1016/j. msea.2005.08.167.

23. 23. Luo, S., Yi, L., Zheng, Y., Shen, J., and Guo, S. (2017). Crystallization of polypropylene in multilayered spaces: Controllable morphologies and properties, European Polymer Journal, vol. 89, pp. 138149, DOI 10.1016/j.eurpolymj.2017.02.013.

24. Poletto, M., Zattera, A. J., Forte, M. M.C., and Santana, R. M.C. (2012).Thermal decomposition of wood: Influence of wood components and cellulose crystallite size, Bioresource Technology, vol. 109, pp. 148-153, DOI 10.1016/j.biortech.2011.11.122.

25. Qian, X., Guo, N., Lu, L., Wang, X., Wang, H., and Shao, G. (2018). Effect of Phosphorus-Based Flame Retardants and PA6 on the Flame Retardancy and Thermal Degradation of Polypropylene," Polym. Plast. Technol. Eng., vol. 57, no. 15, pp. 1567-1575, DOI 10.1080/03602559.2017.1410842.

26. Al-Salem, S. M., Sharma, B. K., Khan, A. R., Arnold, J. C., Alston, S. M., Chandrasekaran, S. R., and Al-Dhafeeri, A. T. (2017). Thermal degradation kinetics of virgin polypropylene (PP) and PP with starch blends exposed to natural weathering, Industrial and Engineering Chemistry Research, vol. 56, no. 18, pp. 5210-5220, DOI 10.1021/acs.iecr.7b00754. 